\title{
SUMMER SOLSTICE CEREMONIES PERFORMED BY BIRD JAGUAR III OF YAXCHILAN, CHIAPAS, MEXICO
}

Carolyn TATr

Division of Art History,

University of Texas

The sculptural styles of different Maya cities, while conforming to the canon of figural representation that is uniquely Maya, can also easily be identified as those of a particular city. Similarly, epigra. phers begin to recognize that each city, while operating from the same cultural and linguistic premises, gave precedence to specific types of events in its historial record. Tikal, for example, in addition to accessions, recorded mostly Period Ending dates on its stone monuments. Palenque rulers thought it important to clarify the history of births and accessions of the various rulers of the site as well as the births and significant actions of the Maya supernatural ancestors. The events recorded at Yaxchilan are mostly not on Period Ending Dates, nor do they focus on the activities of supernaturals. At Yaxchilan, the major classes of events are historical captures, autosacrifices by males and females, and other ritual events. These "other" events, the miscellaneous categony, if you will, form a large portion of the monumental inscriptions. Many of these events were periodic commemorations of similar events by earlier rulers. (Tate 1984). Another group of important ritual events occurred in conjunction with several specific solar phenomena: the first annual passage of the sun over the zenith at Yaxchilan, and summer solstice.

This paper focuses on eight events in the lifetime of Bird Jaguar III of Yaxchilan which fell on or near the summer solstice. It examines the pictorial iconography and the hieroglyphic texts associated with these events which are specific to summer solstice ritual at 
this site, and reports my recent observations of solar-architectural phenomena occurring at summer solstice sunrise.

The evidence for my stoggesrion that stumer solstice was a ritually important station of the solar year comes from my own glyphic anci iconographic analyses of the Yaxchilan monuments, which took as a starting point Proskouriakoif's discoveries (1963, 1964), and iconographic analyses. Since no other atuthor has discussed summer solstice dates recorded in monumental inscriptions, I have turned to etnographic accounts of modern Maya beliefs concerning the phenomena of the solar year to try to clarify meaning.

In order to establish a framework of historical events at Yaxchilan, I have perforned a structural analysis on every text at Yaxchilan that does not demand a great deal of reconstruction due to erosion. This enabled me to compile a master list of all known dates at Yaxchilan. All Maya dates have been converted to Julian dates using Thompson's original 584285 correlation number (Lounsbury 1982). I have checked for possible planetary importance in the Tuckerman Tables (Tuckerman 1964). This table was also to determine the exact dates of summer soletice in the lifetime of Bird Jaguar. III. Dates for zenith passages were arrived at by extrapolating from a table given by Aveni (1980: 66), and thus far checked only by censulting Sr. Angel de Jesús Noveto Sarabia, a guard at Yaxchilan. Using a simple method explained in a previous paper (Tate 1984), 1 have checked for periodicity between the dates at Yaxchilan by dividing intervals between dates by numbers important to the Mayas. This study has led to a fuller understanding of the nature of ritual performance at Yaxchilan. In studying Yaxchilan, I have worked not only with the inscriptions but also with the pictorial iconography, and have done comparative studies of costume, headgear, objects, conventional pictorial format, use of paint on the sculptures and buildings, etc. A basic assumption that I have followed in these analyses is that the texts and images of each structure were programmed as a unit of meaning.

\section{Ethnographic Accounts of Maya Beliefs Concerning the Importance of Summer Solstice}

Only a few authors have gathered information on indigenous observation of and consideration of annual solar phenomena among modern Maya communities, and virtually no accounts dating from the Colonial period exist. 
Rafael Girard worked among the Chorti Mayas of the Motagua River area, and he had a penchant for uncovering Maya astronomical practices. He devoted chapters in his book, The Maya (1966), to topics such as the Chorti's beliefs concerning Jupiter, the solstices, the zenith passages, Venus, etc. Though more recent ethnographers may disagree with his methods and findings, he nevertheless provides information available nowhere else.

- Girard gives an account of the indigenous ceremonies revolving with the solar year. He notes that the first zenith passage beralds the time for planting the fields. "Cuando no arroja ninguna sombra al mediodia, es señal evidente de que "Nuestro Señor anda derecho.'... Esta es la posición que permite al dios bajar verticalmente del cielo a la tierra para fecundarla" (Girard 1966: 121). To symbolize or determine this vertical axial connection when the sun passes directly overhead, Girard mentions that the Chorti make use of a gnomon.

As Girard describes them, the rituals concerning the seasons of the year function on several levels of the society: celestial, political and agricultural. The rituals of summer and winter solstice involve the fositioning of a statue, or idol, in one of two temples. The Chortis know that summer solstice is the day that the sun reaches its northernmost declination in the sky, and that on winter solstice the sum is furthest south. According to Girard, they duplicate this celestial division of the year through a ceremony in which an idol (obviously signifying the sun) is carried from a southerly temple to a northerly one on winter solstice and back again on summet solstice.

In the sphere of political religious leadership, the solstices are the entry and exit points of service for the sacerdotes, each of whom serves an eighteen months term. Entering service on winter solstice, the first twelve months, or year of his service, the sacerdote honors the chair of the idol that signifies the sun. When winter solstice returns, he begins a period of relative inactivity, in which he devotes himself not to interceding to the deity, but only honoring the vacant seat of the idol which is ensconced in the other temple. Summer solstice marks the day that he terminates his duties, having passed responsibility on to the new sacerdote who has had the benefit of a "backup" sacerdote for the previous six months. The ceremonies on the solstices begin among the Chorti on the 20 th or 21 st of June in one temple, and continue for two or three days when the chair and its statue arrive in the second temple on the 23rd. 
The rites performed in the temples are performed in a parallel manner by the paterfamilias in the milpas. "Asi se transforma una labor agricola en un acto ritual" (Girard 1966; 126). In the Maya Central Lowlands, the duties of the agricuitural year correspond to the division of the year by the transit of the sun. The first zenith passage, which varies according to latitude, but in the Chorti area is about 1 May, is the time to plant, because the rainy season usually begins shontly thereafter. The rains continue until the summer solstice, after which begins the canicula or temporary dry spell, during which a second planting is accomplished. The canicula lasts roughly until the second zeaith passage in the beginning of August. when the rains fall beavily again until approximately the equinox.

Similar concepts of the solar half-years are documented in a totally different area, the Achi communities of highland Guatemala, by Helen Neuenswander (1981),

The Achi are aware that the sun is in the south in the beginning months of the dry season and in the north in the beginning months of the rainy season. The concepts which find fullest linguistic expression are conrerned with the size of 'our father', the sun, his position (he, too, lies on his side), his sudden conversion from one length of day to another and his relationship to the seasons... In June, the process reverses and the days become 'short' (on what is, to a Westerner, the longest day of the year). Another application of the concept of 'grabbing onto the pattern to come' seems to be operating here. (Neuenswander'1981: 147-148).

A recent study among the Tzotzil Maya of Zinacantan, Chiapas. reports that these contemporary Maya are acutely aware of the solstices. The summer solstice is called snatil, literally "(the sun's) longest path or point"; the winter solstice is called skomot, literally "(the sun's) shortest path or point". The sunrises and sunsets, and more especially the sunrises, are closely observed on the horizon. (Vogt, in press).

Dr. Vogt suggests that the Tzotziles throught of the Solstice sunrise and sunset points as the four corners or directions of the cosmos, complemented by the center, the navel, Mishik Balamil.

Glyphic Records of Summer Solstice Events at Yaxchilan

In the corpus of inscriptions at Yaxchilan, a group of eight events occurred on or within three days of the actual summer solstice, 
distributed over a period of 48 years (not counting one monument which has no date, Lintel 50) and all within the lifetime of Bird Jaguar III, though he was not always named as the protagonist. The monuments on which the solstice dates are recorded are lintels in Structures 2, 13, 23, one lintel positioned later in front of Str. 40 , and the only stela still standing when the side was visited by Maler in 1903, Stela 11 in front of Str, 41, These monuments were erected at different times. They do not face a uniform direction. Collectively, they face toward the southeastern end of the Great Plaza. So the summer solstice monuments are not all struck by light at the same time of year.

What were the ceremonies through which the people of Yaxchi. lan observed the summer solstice? Let us examine the dates, costumes, and contexts of the summer solstice monuments. (Sce Table 1). The first two times that summer solstice dates appear in the ins. criptions at Yaxchilan are in the Late Classic Period, during the reign of Shield Jaguar ( $\mathrm{r}, 9.12 .9 .8 .1-9.15 .9 .17 .16$, or A. D. 681741). They appear on Str. 23, the ritual structure of Shield Jaguar and Lady Xoc (Tate 1984). The lintels of Str. 23 are inscribed both on the front edges and the undersides. The earliest summer solstice event is inscribed on the front edge of Lintel 26 (See Graham 1977: 3:58). It follows an Initial Series date of 9.14.8.12.5 11 Chicchan 13 Yaxkin (June 20, 720) and accompanying lunar data. A lengthy but eroded verbal phrase can be loosely paraphrased as "fire event" (T122:563) with reference to sacred blood (God C: T1014; See Staart 1983). Lady Xoc performed this event u $c a b$, or under the auspices of, Shield Jaguar (Schele 1982:72; Kelley [962:324).

Six years later, Lady Xoc performed another "fire event", again 4 cab Shield Jaguar. The date, recorded on the underside of L. 23, was 9.14.14.13.17 6 Caban 15 Yaxkin (See Graham 1982: 3:136). This date later was commemorated by the son of Shield Jaguar, Bird Jaguar III, in a manner that numerologically linked his actions to those of Lady Xoc (Tate 1984). Lady Xoc performed these solstice everits when Bird Jaguar was 10.17.15 and 17.1.7 tuns of age, respectively.

"Stela" 16 was originally perceived to be a member of this group on the basis of its unusual iconography. It is published only in a very small format by Morley (1938: V: 104c; see Figure 1), and has not received much attention by epigraphers. The monument was discovered by Maler on the slope in front of Str. 41 , where 
four large stelae commemorating the captures of Shield Jaguar were also found. Measuring $1.96 \mathrm{~m}$ by $0.76 \mathrm{~m}$ by $0.25 \mathrm{~m}$ thick, it is much smaller than any of the other stelae at the site. It is carved on one side in very low relief, and its iconography is similar to several other lintels $(9,32$, and 50$)$. It shows a single figure holding a tall staff to which is attached a strip of cloth with quatrefoilshaped cutouts. "Stela" 16 is without a doubt a lintel which must have come from another structure, perhaps from Str. 41. Sufficient documentation does not exist to determine whether it was dismantled from a doorway and deliberately moved, or whether it fell from one of the doorways of Str. 41. If it was moved to form one of the series of Shield Jaguar stelae on the terrace of Structure 41, it must have been considered significant to have this image occupying the relatively public space of an exterior terrace rather than the relatively more private area of the doorway of a temple.

The lintel is badly weathered on the carved surface, but it is possible to discern in Morley's photograph an unusual ornament that appears to be a long necklare to which are attached pendant shrunken heads and a shrunken torso with crossed arms. An identical ornament appears one other place at Yaxchilan, on Lintel 9 (See Figure 4), Close inspection reveals that the entire costume and headdress of "Stela" 16 is identical to the one copied by Bird Jaguar III on Lintel 9.

Morley (1938: 399) states that the $\mathrm{CR}$ is very eroded, but the month date is certainly 19 Yaxkin, and the coefficient of the day name was 6,7 , or 8 . At $\mathrm{C} 3$ can be seen a 5 katum title, so the protagonist is surely Shield Jaguar, the only known 5 katun lord of Yaxchilan. Since all the monuments at Yaxchilan which include flapstaifs (the staffs with quatrefoil-shaped flaps) as part of their symbolism fall within a few days of summer solstice, and within the month of Yaxkin, it seems likely that the correct date for this lintel should also have been near summer solstice.

Possible reconstructed dates for a 19 Yaxkin near summer solstice in the reign of Shield Jaguar are:

$\begin{array}{lrl}6 \text { Cimi } 19 \text { Yaxkin } & 9.15 .3 .16 .6 & \text { June } 24,735 \\ 7 \text { Cimi } 19 \text { Yaxkin } & 9.14 .11 .13 .6 & \text { June } 27,723 \\ 7 \text { Chuen } 19 \text { Yaxkin } & 9.15 .4 .16 .11 & \text { June } 23,736 \\ 8 \text { Cib } 19 \text { Yaxkin } & 9.15 .5 .16 .16 & \text { June } 23,737\end{array}$


I think that 6 Cimi 19 Yaxkin is the most likely date because of a loose pattern in the distribution of summer solstice dates at the site. Generally events seem to have occurred on summer solstice at six year intervals during the life of Bird Jaguar. Between the $\mathrm{L}$. 26 date and L. 23 date; between the St. 11 date and the L. 33 date are six year intervals. The placement of St. 16 date in the year 735 would make it six years prior to the St. 11 date. However, no firm conclusion can be drawn until the monument itself can be examined for a clue to the actual coefficient and day name.

I suggest that on the date 9.15.9.17.16 12 Cib 19 Yaxkin (June $22,741)$, Shield Jaguar, whose approximate age was 95 years, passed the responsibility for ritual function to his son and heir, Bird Jaguar 111. The event was recorded on Stela 11 arcompanied by the image of Shield Jaguar and Bird Jaguar $n$ in exchanging two flapstaffs (See Figure 2). On Stela 11, the profile image of Shield Jaguar, the cutgoing ruler, is physically smaller than that of Bird Jaguar III, who wears a large feather backrack. Thus Shield Jaguar appears less important in the scenc than Bird Jaguat III, although Shield Jaguar is named glyphically as the protagonist of the event. Like the summer solstice events of the Chorti recounted by Girard, this event seems to mark the termination of the duties of the outgoig official. Also similarly to the Chorti ceremonies, the ritual surrounding this change of responsibility at the site may have fasted for five days.

Four days after the flapstaff exchange, the katun was completed on 9.15.10.0.0. Normally, this would have been the occasion of a bloodletting commemorated monumentally by any Maya ruler. However. at Yaxchilan, no monument has yet been found that docutnents such a sacrifice by Shield Jaguar or anyone else on 9.15.10.0.0. But the next day, on 4 Imix $4 \mathrm{Mol}$, a massive sacrificial ceremony took place in which Lady Ik Skull, Shield Jaguar's wife and the mother of Bird Jaguar III, Lady Great Skull, the wife of Bird Jaguar III, a man perhaps related to her, and Bird Jaguar I himself let blood. These ceremonies are documented on four separate monuments in four different structures at Yaxchilan. Perhaps the Period Ending itself was so sacred that only a living ruler could sacrifice blood on that day, and perhaps Shield Jaguar was too old or ill to do so. Perhaps he was longer ritually qualified to do so, since he had passed the flapstaff to Bird Jaguar III in a stummer solstice ceremony. Perhaps to arknowledge this new role for Bird Jaguar III, the royal family let their blood on 4 Imix $4 \mathrm{Mol}$. 
Shield Jaguar lived for another 358 days, but is not recorded as having performed any further events. Bird Jaguar III did not officially acceed to the throne of Yaxchilan, or did not take possession of the accession bundle, for about ten years, until after his mother, Lady Ik Skull, and the other woman associated with Shield Jaguar, Lady Xoc, had died So this flapstaff summer solstice ceremony is not synonimous with accession to the throne at Yaxchilan. Bird Jaguar III seems to have had to fulfill many ritual obligations prior to his accession, such as having an heir and capturing a prominent warrior.

Six years after the Stela 11 event, after the death of Shield Jaguar, but four summer solstices prior to his own accession, Bird Jaguar III performed another flapstaff ceremony, recorded on Lintel 33 of Str. 13 (See Figure 3). The three lintels of Str. 13 all record astronomical events. The outer two lintels, 33 and 50 , show flapstaff scenes. Lintel 33 definitely occurred on summer solstice, while Lintel 50 has no date, but is of a very late and deteriorated style of carving. A "Skull" glyph appears in the nominal phrase, and I suspect that the protagonist is $\mathrm{Ma}$ Kin Ah Skull, the son of Shield Jaguar II and grandson of Bird Jaguar III (See Figure 5).

The next summer solstice date at the site is also the last activity in which Bird Jaguar III is portrayed. Sixteen tuns, six uinals, and twelve kins after his accession, Bird Jaguar III performed another exchange of flapstaff5, this time with the male courtier who let blood on 4 Imix $4 \mathrm{Mol}$. This event is recorded on Lintel 9 of Str. 2, and is dated 1 Eb 0 Yaxkin, 9.16.17.16.12 (See Figure 4). If it parallels the Stela 11 flapstaff exchange, this event could signal a shifting of ritual responsability at the site from Bird Jaguar III to this individual, Lord Great Skull. Bird Jaguar III is recorded as the protagonist of only one later event, the completion of the katun 9.17.0.0.0. on Sir. 10.

On summer solstice, A. D. 766 , a woman performed a ritual which did not include the flapstaff. This event is recorded on L. 38 in Str. 16 as having ocurred on $31 \times 17 \mathrm{Mfol}$ (See Graham 1979: 3: 85). The verb is a hand-grasping-fish glyph which signifies bloodletting (Proskouriakoff 1973), and the protagonist is a lady with the God C "sacred, lineage blood" title (Stuart 1983). The most unique element of this lady's name is an Ahpo Ik compound, so that is the name I use for her. She appeared with Bird Jaguar III two uinals after his accession on Lintel 5 of Str. 1 holding the ritual bloodletting bundle (Greene Robertson 1972): She held the 
bundle again on 9.16.4.1.1 7 Imix 14 Tzec, dates on which Bird Jaguar commemorated the 84th solar year anniversary of Shield Jaguar's initial event on zenith passage, 7 Imix 14 Zotz, 9.11.18.15.1, recorded on Step IV of Str. 44. She also is portrayed on L. 15 in Str. 21, where she is shown kneeling, holding a basket of bloodletting equipment. She gazes upward at a male head, one which looks very much like Bird Jaguar III as he is shown on the other lintels of Str. 21. The head emerges from the open jaws of a serpent floating above a bowl of bloodied paper strips. Thus, Lady Ah POF Ik is ritually associated with Bird Jaguar III, and the summer solstice event that she performs happened within his lifetime, as did all the summer solstice events at Yaxchilan.

\section{The Summer Solstice Costume}

The records of fire events performed on summer solstices by Lady $\mathrm{Xoc}$ on Str. 23 were not accompanied by pictorical imagery. The first illustrated summer solstice event appeared on "Steia" 16. On this lintel (Stela 16), Shield Jaguar was portrayed wearing the costume: that Bird Jaguar III wore for all the subsequent solstice events, except the last one, a bloodletting performed by lady Ahtro Ik. In all examples, the costume consists of a large feather backrack, a GIII (of the Palenque triad) shield, a short hipcloth decorated with beads or jaguar claws, a long jade bead perforated and worn horizontally, beaded kneebands, wristlets, and anklebands, an elaborate headdress, and a unique pendant worn by the rulers of Yaxchilan on which is carved a profile seated jaguar.

In every case the protagonist hoids at arm's length a staff about the same height as himself. At Yaxchilan, the staff is unique to the summer solstice events, I suspect that it is made of a wooden orbamboo stick or armature to which is attached a piece of cloth. Cut from the fabric at regular intervals are quatrefoil shaped flaps which are cut on only three of the four sides of the quatrefoil and thus stick out from the cloth. Bird Jaguar III generally grasps the flapstaffs through one of the cutouts, and his closed fist must also grasp. some solid support.

What could the flapstaffs represent? Since they are used at Yaxchilan only on the occasion of summer solstice, one suspects that they have some astronomical significance, and perhaps were used ns gnomons. The use of a gnomon would be more suitable to de- 
termine the day of zenith passage, when at noon the staff would cast no shadow. It could also have been placed on a flat surface and used to determine true north and to gain information about the daily motion of the sun. Why would a gnomon have quatrefoilshaped flaps?

The quatrefoil symbol appears in Maya art in Early Classic times. It is inserted in pictorial compositions in a variety of situations, all of which can be constructed to be an opening from one realm into another. For example, on Tikal Altar 4 (Jones and Satterthwaite 1982: Figure 58), the mouths of the profile Cauac Monsters are given clearly quatrefoil (or semi-quatrefoil) shapes. From inside these mouths emerge aged figures who wear shells as lower body coverings, and may be identified as God N, one of the Lords of the Underworld. Thus the Underworld gods are emerging into terrestrial space through the mouths of the Cauac Monster, clearly marked by quatrefoil shapes. An example of the opposite situation, a human entering the supernatural realm, can be seen on the Vase of Enthroned Gods (Coe 1978; Number 16). There a human enters the Underworld realm through a quatrefoil which is the base or opening in the world axial tree. There are many examples of the use of a quatrefoil as a framing device for ancestors and their portraits, notably the stuccoes on the interior wall of House A at Palenque, and the ancestor portraits framed by semi-quatrefoils which appear around the edge of Pacal's Sarcophagus Lid at Palenque, So as not to digress too far from the present topic, I think that the evidence for quatrefoils symbolizing the openings between realms along the central axis of the layered Universe is overwhelming. With this interpretation, then, the use of the flapstaff must have been part of an ancestral recall ritual or one in which supernaturals were called upon to manifest their presence. More practically, quatrefoil shaped holes can also be used to sight the relative distances of heavenly bodies along a straight stick marked with intervals of measurement, supplemented with some aritmetical calculations. The association of ancestors with stars keeps this suggestion from being too far-fetched (Thompson 1970: 301-302).

However, the evidence that the flapstaff was used as a gnomon really does not exist. There are no images of this activity in progress at Yaxchilan, and no evidence from the Classic. Period that suggests that the Classic Mayas indeed used such devices. Of course, the Mayas seldom portrayed themselves in any ritual activity save bloodletting. As for more contemporary documentation of the use of gno- 
mons, Girard, as mentioned above, does say that the Chorti used them in their astronomical endeavors.

On "Stela" 16 and Lintel 9, the first and last dated of the flapstaff monuments, Shield Jaguar and Bird Jaguar III wear a unique and gruesome front ornament. From what 1 can determine from Moriey's photograph, Shield Jaguar wears two suspended shrunken heads and a shrunken upper torso, all attached to a cord which is tied around the back of his neck. Some cut spondylus shelis alternate with the heads on the ankle-length necklace. Bird Jaguar III apparently has added three additional heads to the assemblage.

On these two monuments, an identical headdress is also worn. It is tall and shaped similarly to the thatch headdress frequently worn at Yaxchilan on occasions when the birdstaff or the God $\mathrm{K}$ manikin sceptre is canied. (The occasions are the Jupiter-Saturn aligment event, Bird Jaguar III's aecession, the two month, five tun, and six tun anniversaries of his accession). The flapstaff-associated headdress is unique, however, for several supernaturals $\propto$ cupy various positions on the headdres. A Cauac Monster head faces front and as a seat for a crosslegged tiny supernatural, perhaps God $\mathrm{K}$, who holds a human head. To the rear of the Cauac Monster head, the head of GI of the Palenque Triad emerges from a serpent mouth. Another serpent pops up from the top of headdress. Several other ormaments appear: a stack of seven bows near the back of the headdress, a series of three bows tie on a miniature flapstaif, and two mirrors, one infixed with a God $\mathrm{C}$ "blood" emblem emerge from the top of the headdress, I am not aware of any other headdress quite like this from any other Maya site, so it is difficult to assess its precise significance.

\section{The Glyphic Texts}

Lady Xoc's summer solstice events recorded on Lintels 23 and 26 of Str, 23 are verbally characterized as "fire" events. (T 59: 1035). Six "fire" events are recorded at Yaxchilan, and Lady Xoc is the protagonist of four of them, ne of which is posthumous. Except for the posthumous event, all of the "fire" events are characterized as having taken place "in the house" (no Thompson number. apply; see L. 23 N6a in Graham 1982: 3:186). The first "fire" event was performed by Shield Jaguar on zenith passage, recorded on Step IV of Str. 44. The next two chronologically were performed on summer solstices six years apart by Lady Xoc and the last three 
are anniversaries of previous important events, So it is impossible for me to say at this point exactly what the significance of these events is, only that the glyphic phrases for each is quite similar.

All monuments on which a flapstaff is portrayed are inseribed with very similar verbal phrases, (See Figure 6). This compound can be said phonetically "mul tah ti $a h k^{\prime} a$ wa' chan". Kathryn Josserand and Nicholas Hopkins, working on the Chol language, have suggested possible readings for this phrase (Personal Communication, April, 1985). Following the date is an auxiliary verb. T516: 103:583 with is read mul tah (Schele 1982: 65). The following compound can be broken into syllables:

$\begin{array}{rll}39 & h & \text { to on } \\ 683 & \text { at } & \text { He ? } \\ 563 & k^{\prime} a & \text { again } \\ 130 & w a & \text { standing } \\ & w a^{\prime} a l & \text { stopped } \\ 583 & \text { chan sky }\end{array}$

The phrase appears to concern a repeated action of the standing or stopping (of the sun in its path?) in the sky. It is similar to the previously mentioned Tzotzil expression for summer solstice, siatil, the sun's longest path or point.

\section{The Appearance of the Flapstaff at Other Sites}

In what contexts was the flapstaff used at other sites? A search of the corpus of known Maya monuments for additional images of flapstaffs held in the hand of a human yielded six monuments: Balancan-Morales Stela 4 (Lizardi Ramos 1961), the Cleveland and Kimbell stelae (Miller 1974: 151 and 157), "Site Q" Stella 4 (unpublished), Tikal Temple IV Lintel 2 (Jones and Satterthwaite 1982: Figure 73), and E1 Cayo Lintel 1 (Maler 1903: Plate XXXV), A survey of the dates of the monuments (See Table 2) indicates that the flapstaff did not originate at Yaxchilan.

The lengthy text of Balancan Stela 4 appears to be a record of the life of a ruler, beginning with his birth on 9.11.3.5.14 $10 \mathrm{Ix}$ 7 Kayab (January 17, 656). It is not clear which of the events the carved scene illustrate or whether it simply presents and idealized ligure. 
The stela in the Cleveland Museum of Art (Miller 1974:151) portrays a fernale holding the flapstaff. The text on the front gives the date 6 Manik $5 \mathrm{Zip}$, corresponding to 9.12.13.17.7, and the verb following this CR is a "hand holding God K mirror", known to indicate accession (Schele 1982: Chart 126:4). The stela records the accession of Great Jaguar Paw to the throne of the site, (now thought to be "Site $Q$ ").

Not enough of Site Q Stelae 1 (the Kimbell Stela) and 4 texts survive to ascertain that the presence of the flapstaff is associated with an accession, although it seems likely. The four monuments just mentioned all date before the earliest flapstaif monument at Yaxchilan, and their dates do not fall near summer solstice. It may be possible to generalize that those monuments with flapstaffs that predate the Yaxchilan ones primarily depict accessions.

On Lintel 2 of Temple 4 at Tikal appears a highly elaborated staff with quatrefoil shaped cutouts. In the quatrefoils appear blunt nosed supernaturals wearing the masks of longer nosed supernaturals. The first recorded date on this lintel is 3 Ahau $3 \mathrm{Mol}(9.15 .10 .0 .0)$, which is one day prior to the triple bloodletting on 4 Imix 4 Mol at Yaxchilan. As mentioned above, this date fell five days after the exchange of flapstaffs by Shield Jaguar and Bird Jaguar III recorded on Stela 11. So the date of the appearance of this, the only flapstaff at Tikal, is on June 26,741 , a few days after the summer solstice that year, and contemporary with the solstice events on Yaxchilan Stela 11.

Two sites in the political sphere of Yaxchilan, EI Cayo and La Pasadita, used the flapstaff as accession iconography after Bird Jaguar III used this solstice ceremony as a par of the propoganda scheme with which he attained rulership at Yaxchilan. The most elaborate of the carved lintels of El Cayo is carved with the image of a ruler holding a flapstaff. The surface of Lintel 1 is quite eroded, and many gliphs are difficult to distinguish. The initial Series date is 9.16.4.3.16 $10 \mathrm{Cib} 9 \mathrm{Mol}$, the birth of the primary protagonist of the lintel. This date corresponds to June 29, 755. The next continues to give information about the political career of this ruler's father, and eventually tells of his own accession. It is probably as an element of the accession ceremony that the flapstaff occurs on the lintel. The date of Lintel 1 is a little more than four tuns after the accession of Bird Jaguar. III at Yaxchilan, and suggests that Bird Jaguar III's political influence, once established, extended into the sites in the central Usumacinta region, 
Lintels from the site of La Pasadita, Guatemala, mention Bird Jaguar III and his son, Shield Jaguar II. A mural fragment from the site, now in the Guatemala Museum, shows an individual holding a flapstaif, though the accompanying glyphs are too eroded to detemnine the date or event portrayed.

The construction of the flapstaffs on these monuments is more clearly shown than on the Yaxchilan monuments. On the Kimbell and Cleveland Stelae, the flapstaff assumes some serpent characteristics. The framework is some rigid material, possibly wood or bone, that is formed into the shape of a skeletal serpent with an upward-curling snout. The material from which the flaps are cut it attached to this armature, and here, due to the gathering of the material, it is elear that the flaps are cut from cloth of some sort. At the end of this small flapstaff is a tied up ball from which a section of fabric hangs loosely. A stiff tuft of fabric bristies from the top as the staff is held upright.

Alignment of Atchitecture as Evidence of the Importance of Summer Solstice at Yaxchilan

In my studies of the planning and execution of architecture at Yaxchilan (forthcoming) it has become clear that Bird Jaguar 111 was responsible for extensive reshaping of the plan of Yaxchilan. Until the archeological reports are available, the appearance and layout of the site before his era will remain a mystery, but it is obviously that he designed a major portion of the structures extant today. The iconography contained within those structures was also strategically planned to demonstrate his adherence to the ritual traditions established by his father and earlier rulers. The summer solstice/flapstaff ceremonies, though established by Shield Jaguar ("Stela" 16), seem to have become Bird Jaguar III's hallmark.

Bird Jaguar's structures occupy what is now the central area of the site, Because it contains the lintels which record his accession, and is the focal point of a larger composition of buildings which document the events which took place before his accession, I call Str. 33 Bird Jaguar III's accession structure. Inside the structure is the only known full scale three dimensional stone sculpture of a human at the site, which I believe is an accession portrait of Bird Jaguar III. (See Maler 1903: Figure 37). This figure was found on a bench built on to the rear wall of the structure, immediately 
behind the central doorway. Str. 33 is in the center of the site, both in terms of area and elevation. Stela 1, the long stairway up to Str. 33, and Str. 33 itself create an obvious ceremonial axis around which other structures important to the documentation of Bird Jaguar's reign are more or less symmetrically arranged. Bird Jaguar III planned the dispositon of his monuments so that multiple records of im. portant events encircled the central axis of his area, and surrounded the statue of himself. (The arguments for these statements will be provided in my forthcoming dissertation). This is exactly how the summer solstice monuments are distributed.

In 1984, I travelled to Yaxchilan with a crew of assistants to observe the interaction of the sunlight with architecture. Prior to my trip, I had deternined the expected position of the sunrise and sunset azimuths, I wanted to know where the sun appeared over the hills of Guatemala to the north east on summer solstice when viewed from the original locations of the summer solstice monuments.

On Wednesday, June 20, 1984, two members of the team, James Strickland and Tabor Stone were on the terrace of Str, 33 before sunrise preparing to take readings of the point on the horizon at which the sun appeared when standing in the central doorway of Str. 33. From this position, the sun rose through a pronounced notch in the hills at $62.5 \mathrm{E}$ of $\mathrm{N}$. Strickland realized that the first rays of sunlight were streaming through the doors of Structure 33, and turned around to see that the statue of Bird Jaguar III, positioned against the rear wall on the interior of the building, was fully illuminated. The rising sun at summer solstice shone on the statue of Bird Jaguar III for seven minutes after which the statue was again shadowed by the roof and piers of the structure.

Stone joined Strickland while the sun was still illuminating a portion of the torso of the statue. He determined that the axis of Str. 33 perpendicular to the elevation, taken through the central doorway, follows a compass bearing of 54 which is approximately 8.5 to the North of the point of sunrise. Stone, Strickland, and I concluded that the orientation of Str. 33 deliberately provided for the illumination of the statue during the summer solstice sunrise. The fact that at about this station of the year a canicula, or dry spell, begins, as mentioned by Girard, is supported by the observation that it did not rain a drop on Yaxchilan during the days surrounding summer solstice in 1983 and 1984 , when I was at the site. Maler also experienced the canicula in 1895 (Maler 1903: 110). 
In ancient times, if the weather patterns were similar, the sunrise might not have been obscured by clouds on summer solstice. Had Str. 33 been situated to directly face the position of sunrise on the horizon, the illumniation of the statue would have been only momentary.

Schele has posited a similar function for some of the architectural assemblages at Palenque (Schele 1977). She asserts that "The place of Palenque seems to have been defined in terms or Late Classic Maya geography and cosmology as the western portal of the underworld, where the sur, the moon, and the cyclic gods died", (Ibid: 56). She noted that two structures at Palenque, the Temple of the Inscriptions, the tomb of Pacal, and the Temple of the Cross, the suspected tornb of Chan Bahlum, were part of a dramatic scenario at winter solstice sunset. At about 2:30 in the afternoon, the sun disappears behind the ridge and appears to sink into the Temple of the Inscriptions, The sunlight still streams through a ravine from behind that hill toward the Temple of the Cross. There, the last rays of the sum before-sunset at the site fall upon the image of God $L$, identifed as one of the chief gods of the Underworid, placed on the doorjamb of the interior sanctuary of the temple. This illumination was "designed to make site itself, or perhaps the universe reproduce, for all to see and understand, the cosmological foundation of rulership", (Ibid: 50 ).

\section{Condasions}

Architectural assemblages designed as solar observatories have been posited for the Maya area since Ricketson's discovery of the wellknown solar otservatory at Bidg. E-VII sub of Eaxactun (Ricketson 1928). Sirce then, archeoastronomers have primarily examined architectural layouts for evidence that they were used as celestial observatories, or were designed to replicate perceived celestial organization. I believe that at Yaxchilan, the planning of the ceremonial center was done primarily for propagandistic and ritual purposes, and that the architecture, its decoration, and the architectural space was meant to be read as a series of intersecting and overlapping political and cosmological statements.

I do not feel qualified to state that Structure 33 functioned as a solar observatory. I am confident, however, that the series of dates during the lifetime of Bird Jaguar III at Yaxchilan which fell upon summer solstice did not do so coincidentally. 
That the costume and regalia of the summer solstice events is as identical as sculptural style at the site allowed is a strong a: gument against the dates falling randomly on summer solstice. The people of Yaxchilan considered that the ceremonies on these dates were equivalent, as shown by the repetition of verbal phrases on the solstice monuments.

The information gathered by Neuenswander, Vogt and Girard among twentieth century Maya groups shows that the Ixal of highland Guatemala and the Chorti of the Motagua region were aware of and used indigenous concepts to express the phenomena of summer solstice. Among the Chorti, summer and winter solstices were perceived as a time of a shift in power from one individual to another at the site. The shift in political power mirrored a similar shift in the celestial realm from north to south dominance, and the summer solstice and zenith passages were also important stations of the agricultural year as well. To symbolize the transition in celestial and religious leadership at the site, the Chorti multi-day solstice rituals included the transport of a status and its seat from one temple to another. This practice is reminiscent of the solar illumination of the statue of Bird Jaguar III on its bench.

At Yaxchilan, the summer solstice ritual involving an exchange of flapstaffs between Shield Jaguar and Bird Jaguar III clearly marks the termination of the effective reign of Shield Jaguar. Four days after this event, on 4 Imix 4 Mol 9.15.10.0.1, Bird Jaguar III, Lady Great Skull, Lord Great Skull, and Lady Ik Skull were reconded as having let blood on three separate monuments in three structures. This is the only date at Yaxhcilan in which more than two individuals let blood on the same day. Though we may not realize the exact nature if the significance of this day it was obviously very important, and 1 suspect that it initated a period during which Lady Ik Skull assumed regency of the site for Bird Jaguar III Intil her death.

Thirty-seven years later, Bird Jaguar III exchanged flapstaffs with Lord Great Skull. This man shared the name of Great Skull with the wife of Bird Jaguar III (the mother of his heir, Shield Jaguar II). I suspect that a similar situation of regency might have been in effect after the summen solstice ceremony of 9.16.17,6.12. After this date, Bird Jaguar III was mentioned only once more at the site, in a retrospective historical summary that recordod his birth, accession and the turn of the katun at 9.17.0.0.0, on the consecutively inscribed lintels of Structure 10. The date of Shield Jaguar II's ac- 
cession to the throne is not certain, due to the eroded state and confused syntax of this accesion lintel, I. 10 or Str. 3. This date, 7 Cimi 14 Yaxkin, may be best reconstructed as 9.17.9.9.6., when Shield Jaguar Il would have been 1.8.13.9 tuns of age. By that time it seems apparent that the power that Bird Jaguar III and his father, Shield Jaguar had forged at Yaxchilan had waned soon after the reign of Bird Jaguar.

Lintel 9, the flapstaff exchange between Bird Jaguar III and Lord Great Skull, was situated in the casternmost position of the monuments of Bird Jaguar III at Yaxchilan, near Str. 20, which documents the legitimacy of Shield Jaguar II and the reentry of Lord Great Skull of the ancient Great Skull family into the ruling sphere of Yaxchilan (information about the Early Classic dynasty courtesy of Peter Mathews, personal communication, 1983). Structures on the eastern end of the site appear to have been commissioned by Shield Jaguar 11 . Lintel 9 formed the southeastern end of the row of structures 20, 21, and 22, which contained records of the rituals of Bird Jaguar III. This group of structures, along with the ritual structure of Shield Jaguar, Str. 23, were situated by Bird Jaguar III to flank the monumental stairway which led to Structure 33 .

As Morley commented, "....considering its conspicuous location on the summit of a high natural hill, made over into the Main Acropolis, at the very center of the city, Structure 33 must have been the most imposing building at Yaxchilan" (Morley 1938: 551). Morley and Maler considered that this statue was the representation of a Maya deity, Ketsalcoatl (Maler 1903: 161), but their interpretations were made well before Proskouriakoff proved the presence of historical data and historical individuals in the glyphs of Piedras Negras and Yaxchilan in the 1960 's. It now appears that Bird Jaguar 111, the last great ruler of Yaxchilan, in the course of redesigning the city as a testament to his own legitimacy and ritual piety, deliberately arranged Structure 33 , his accession monument, to document his special relationship with summer solstice sunrise if. a manner that could be observed for many baktuns. 


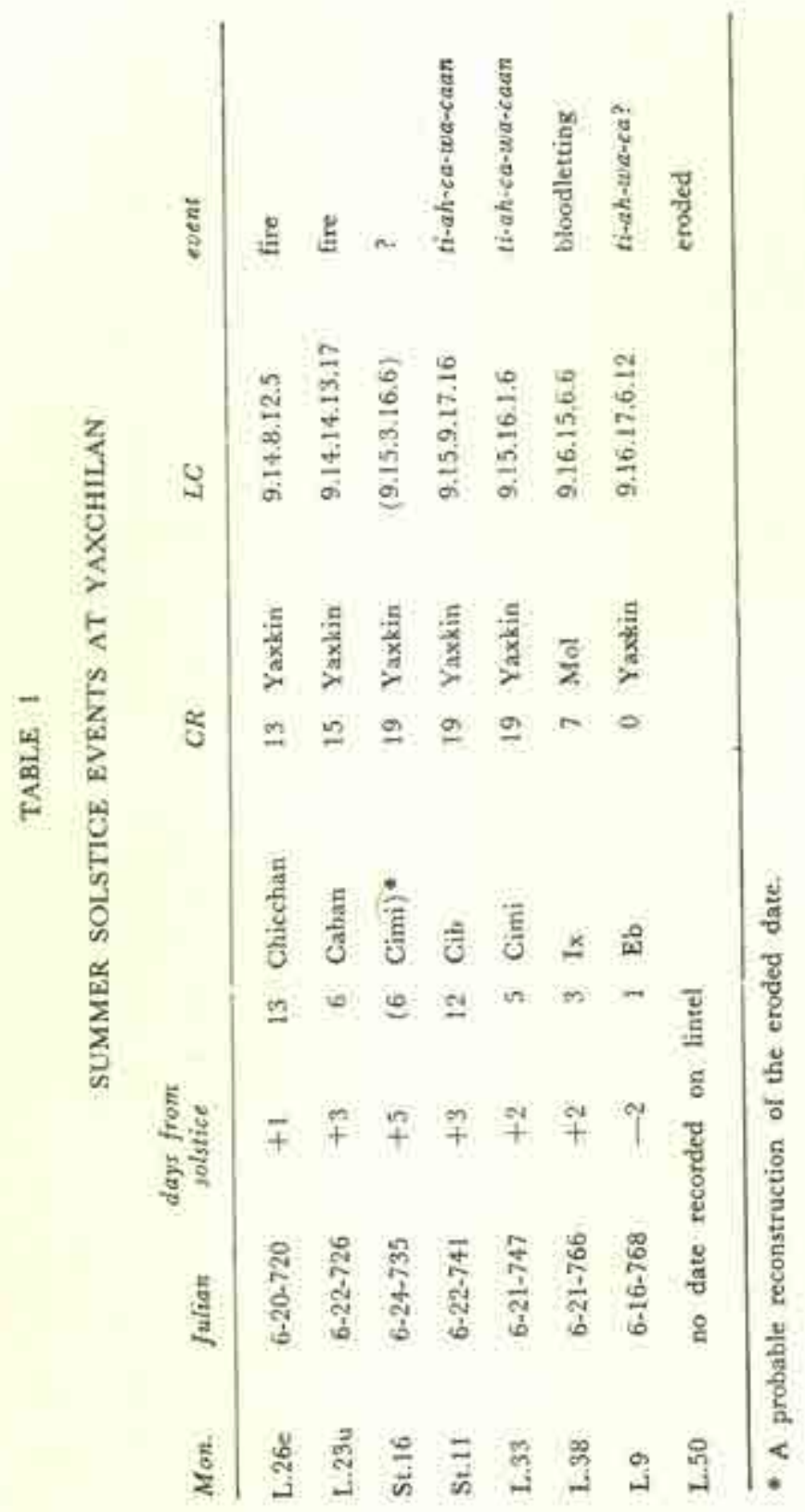




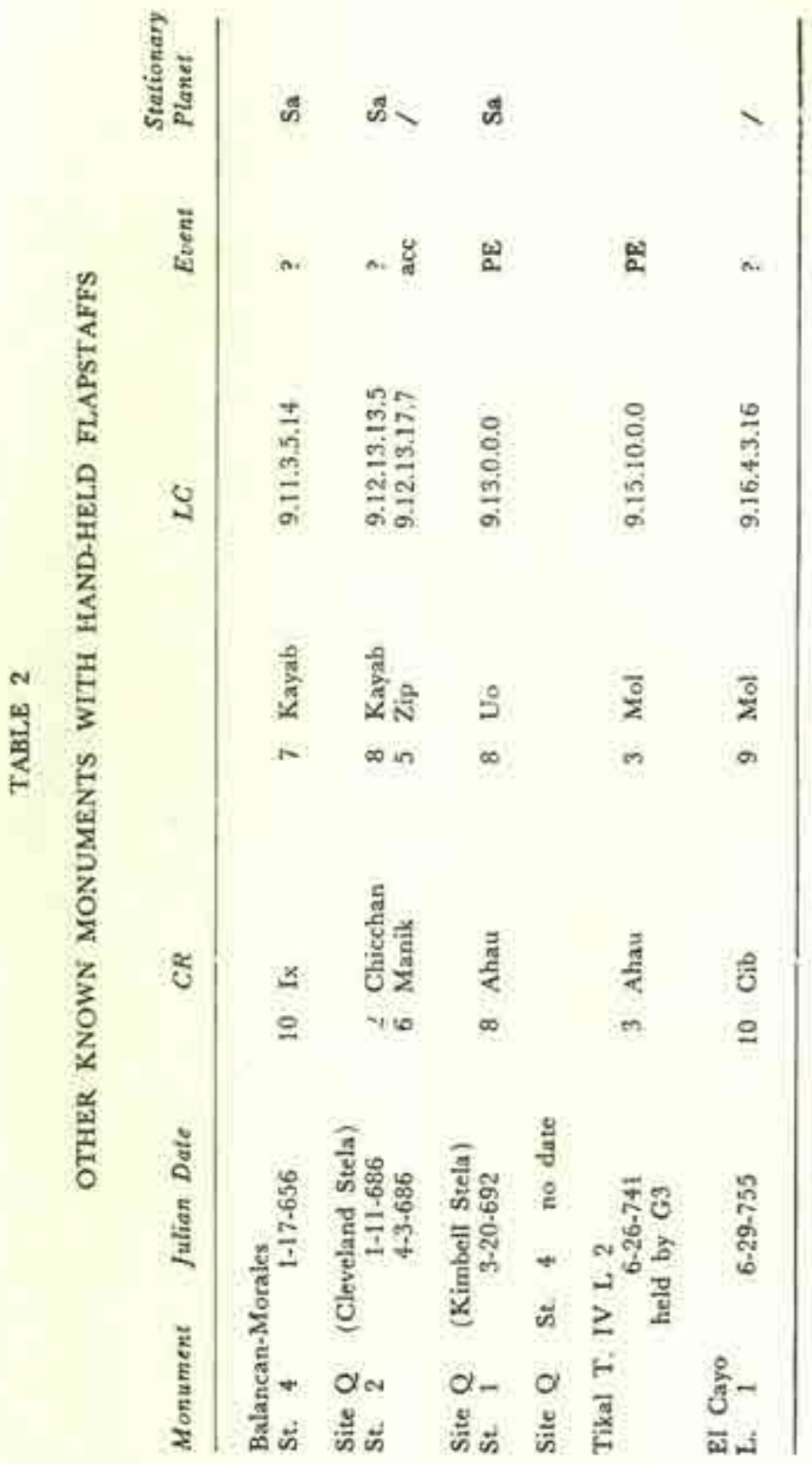




\section{REFERENCES CITED}

Aveni, ANthony F.

1980 Skywatchen of Ancient Mexico, University of Texas Press, Austin.

COE, MiChaki; D.

GLNRD, RAYABL.

1978 Lords of the Underworld, Princeton University Press, Princeton.

GrahaM, IAX

Los Mayas, Libro Mex, México, D. F.

1977 Corpus of Maya Hicroglyphic Inscriptions, Volume 3:1. Peabody Museum for Archaeology and Ethnology, Harvard Unixersity: Cambridge.

1979 Corpus of Maye Hieroslyphic Inseriptions, Vol. 3-2. Peabody Museum for Archaeology and Ethnology, Harvard University, Cambridge,

1982 Corpus of Maya Hicroglyphic Inscriptions, Vol. 3-3. Peabody Museum fur Archaeology and Ethnology, Harvard University, Cambridge.

Grezne Robeatson, Mrki.z.

1972 "The Ritual Bundies of Yaxchilan", Paper presented at the Tulane University Symposium on the Art of Latin America New Orieans. Ms. in possession of the author.

Jones, Chrtstopher and Linton Satterkwate.

1982 The Monuments and Inscriptions of Tikali the Carved Mond. ments, Tikal Report, No. 33, Part A, The University Museum

Ketiafe, Davio $\mathrm{H}$.

University of Pennsyivania, Philadelphia.

1962 Glyphic Evidence for a Dynastic Sequence at Quirigua, Gua temala, American Antiquity 27: 323-335.

Lizardi Rimos, CÉsak

1961 "Las Estelas 4 y 5 de Balancan, Morales, Tabasco", Estudios de Cultura Maya, J. pp. 107-130.

Lounsatry, Floyp G;

1982 "Astronomical Knowledge and its Uses at Bonampak, Mexico", Arehaboastronomy in the New World, edited by Anthony $\mathrm{E}$. MNeER, TrOBERT Aveni, Cambridge University Press, London.

1903 Researches in the Central Portion of the Usumacintla Valley, Memoirs of the Peabody Museum, Harvard University, Cambridge.

Mriter, Jerprery

1974 "Notes on a Stela Pair Probably from Calakmul, Campeche", Merle Greene Robertson (Ed.), Primera Mesa Redonda de Pelenque, Part 1, Robert Louis Stevenson School, Pebble Beach,

Morher, Sruvanus CA., pp. 149.162 .

1938 The Inscriptions of Peten, Publication 437, Carnegie Institute of Washington, D.C.

Neuesnawander, Helen

1981 "Vestiges of Maya Time Concepts in a Modern Community"

Proskourthxort, TAtinkA Estudios de Cultura Maya, XIII: 125-160, UNAM, México.

1963 "Historical Data in the Inscriptions of Yaxchilan, Part One'

Estudios de Cultura Maya III: 149-167, México, D. F. 
1964 "Historical Data in the Inacriptions of Yaxchilan, Part Two". Estudios de Cultura Maye IV ; 177-201, México, D. F.

1973 "The Hand-grasping-fish and Associated Glyphs on Classic Maya Monuments", Mesoamerican Writing Systems, edited by Elizabeth Benson, pp. 165-178, Dumbarton Oaks, Washington, D. C.

Ricketson, Otiver G., Jr.

1928 "Astronomical Observations in the M-wa Area", in Geographical Review, 18: 213-225.

SCHRIE, LINDA

"Palenque: House of the Dying Sun", in Anthony Avent (Ed.). Native American Astronomy. University of Texas Press, Austin, pp. 43-56.

1982 Maya Clyphs: The Verbs, University of the Texas Press, Atutin. STUART, DAVII

1982 "Blood Symbolism in Maya teonography"; Paper presented at the Conference on the Beginnings of Maya Iconography, Princeton University. October 15-17, 1982. Ms in possession of the

TAte, Carotis author.

1984 "Astrononical and Commemorative Everts of Yaxchilan Struc. ture 23: A Mathematical Approach to Hierogiyphic Decipherment", Unpublisbed ms. in possession of the author.

Thostrson, J. Enic S.

1970 Maya History and Religion, University of Oklahoma, Norman.

THCKerman, BRVANY

1964 Planetary, Lunat and Solar Positions: A. D. 2 to A. D. 1649, at

Voot, Evon Z. Five-day and Ten+day Intervals, American Philosophical Society, Philadelphia.

n.d. "Cardinat Directions in Mayan and Southwestern Indian Cos mology", to be published in an Homenaje for Alfonso Vilt. Rojas. 


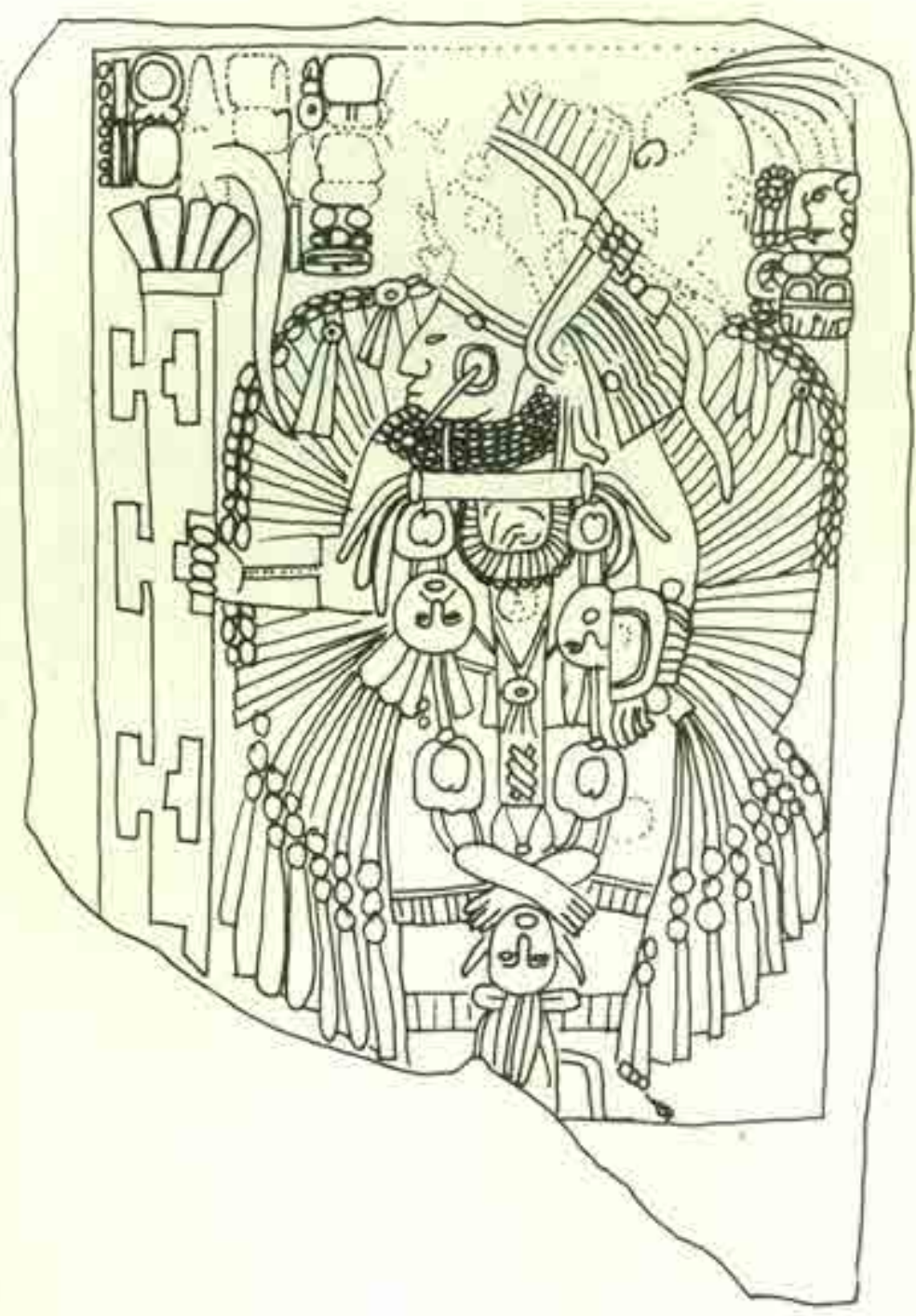

Figure 1. 


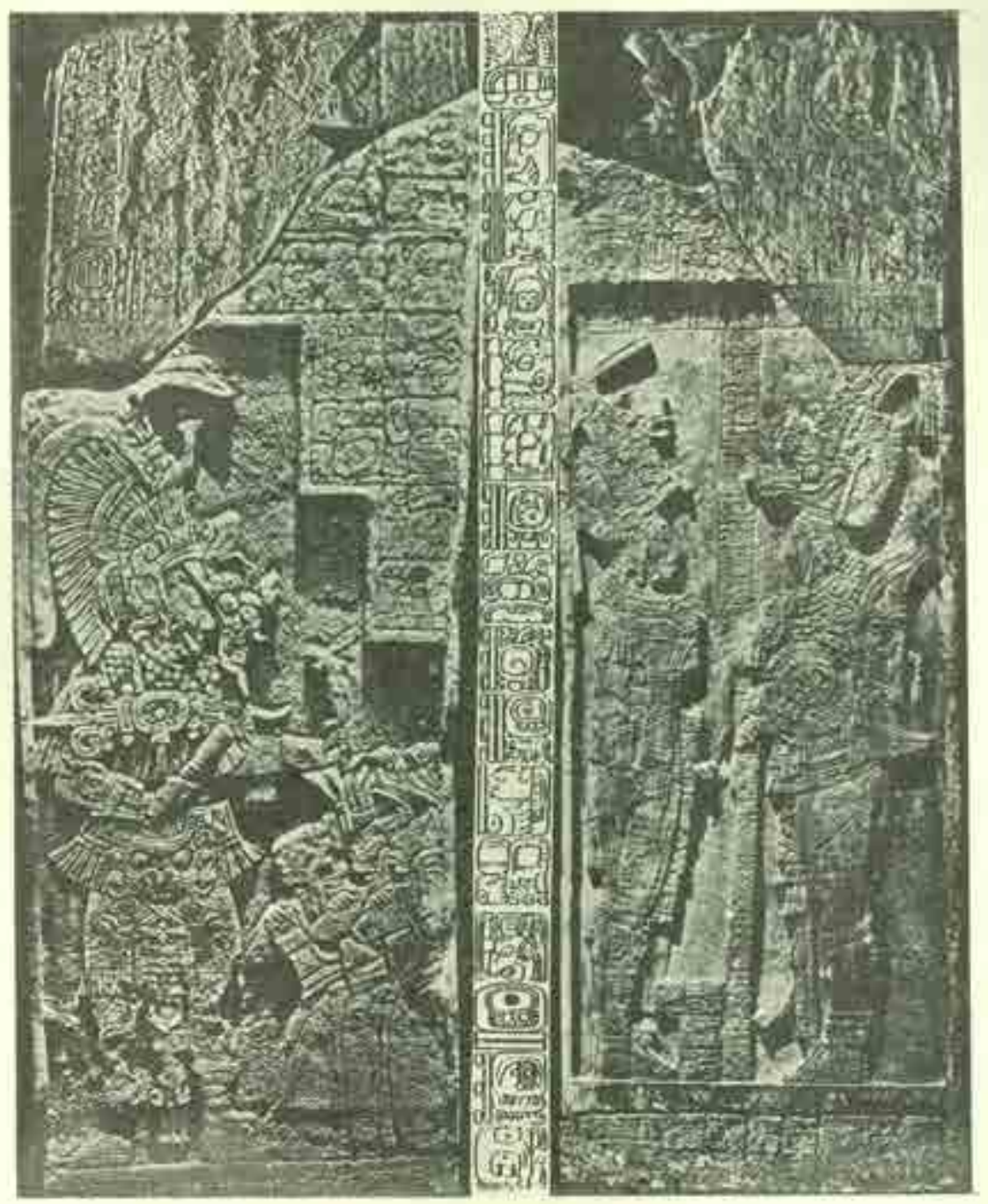

Figure 2. 


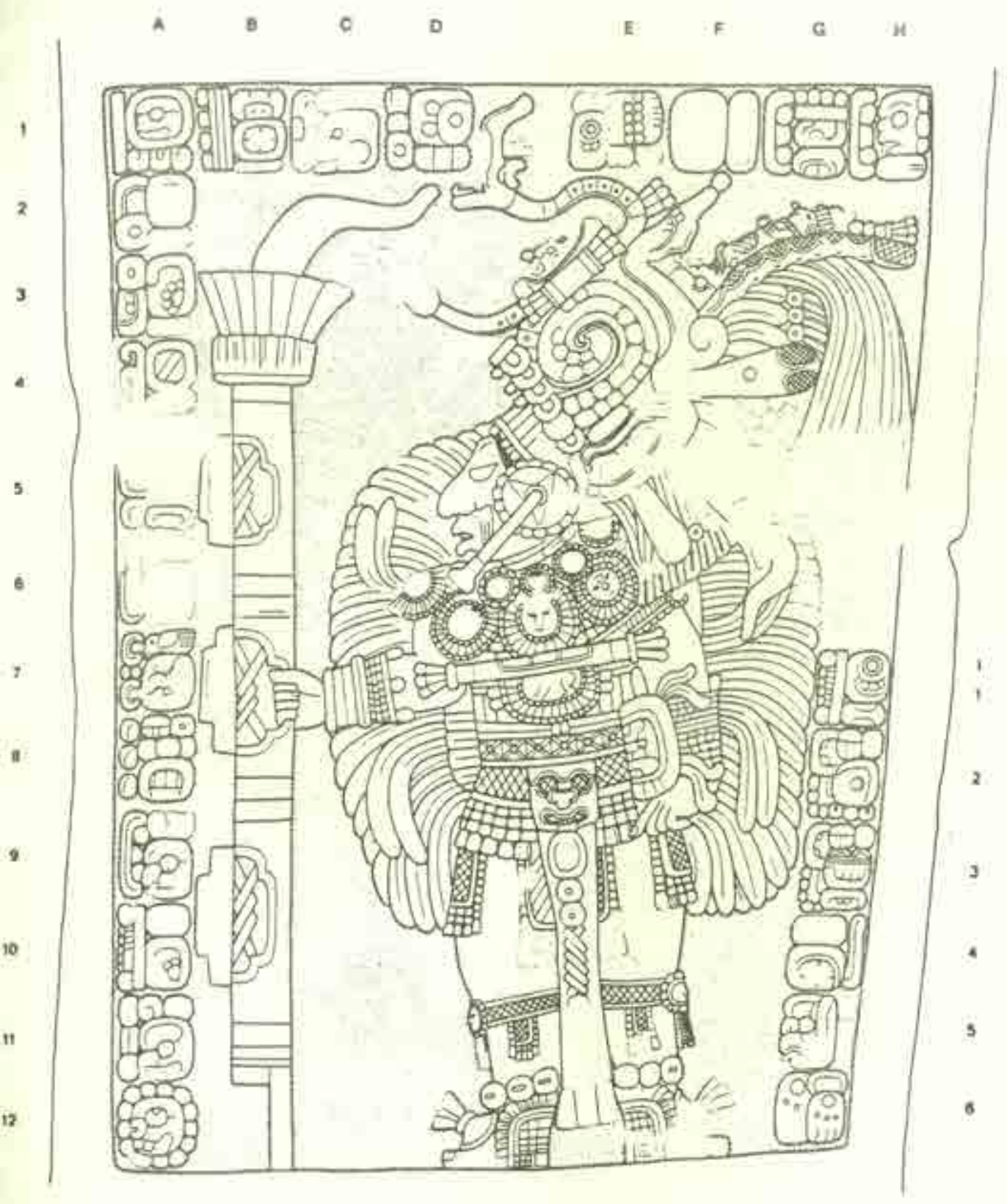

Figure 3. 


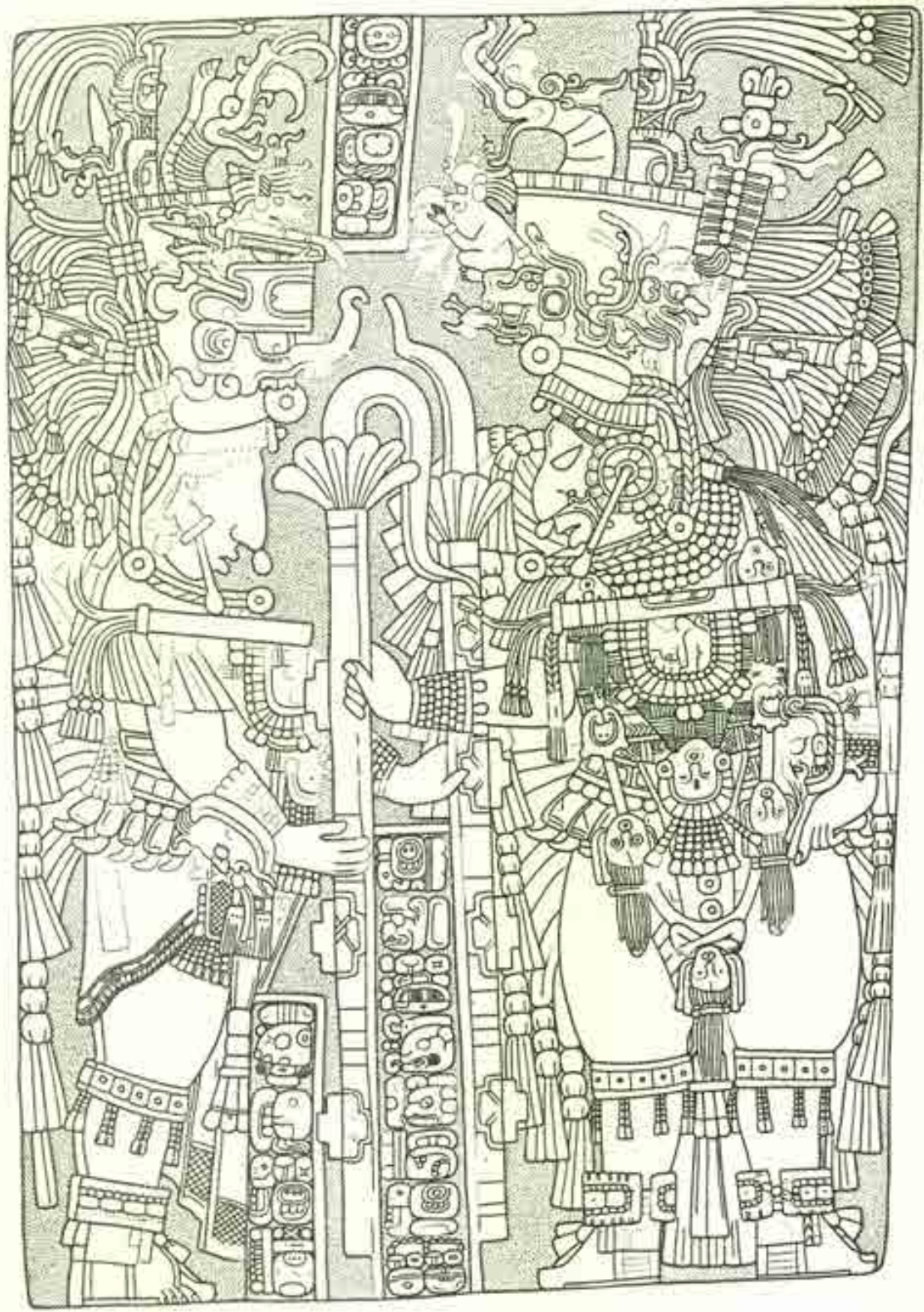

Figure 4. 


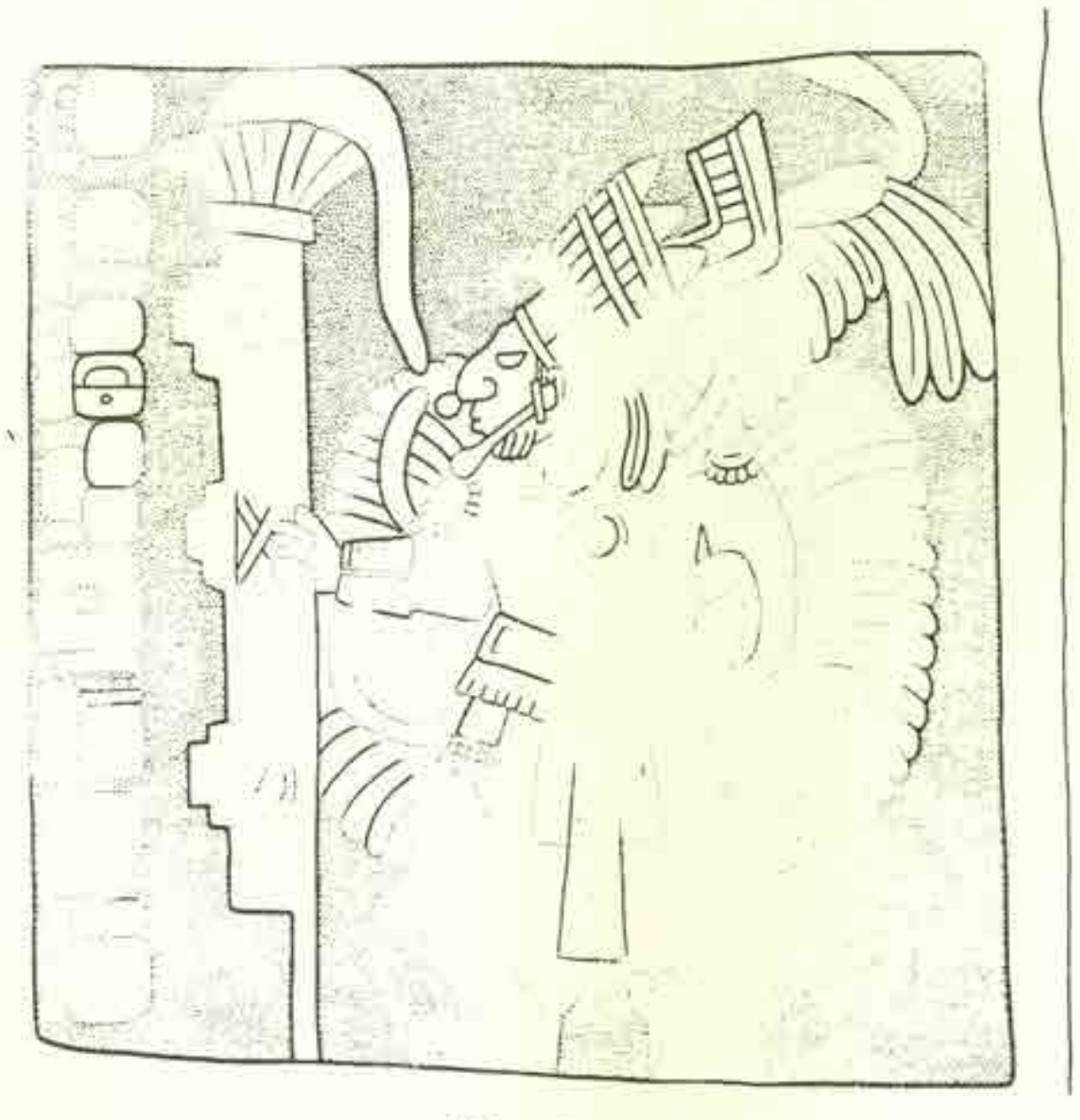

Figure 5. 
a.

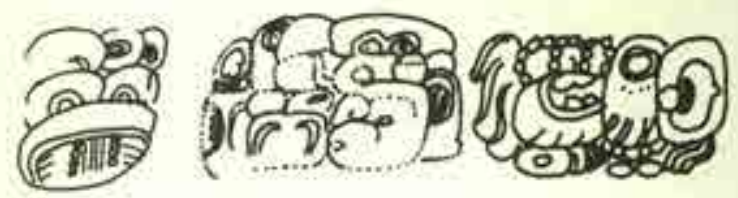

b.

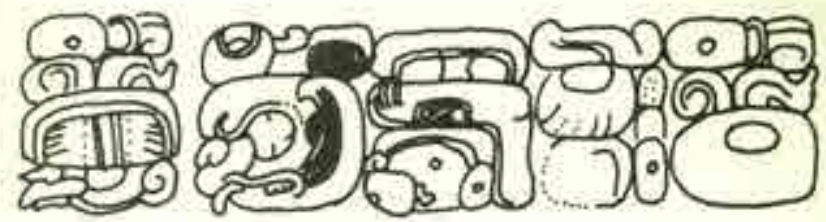

c.

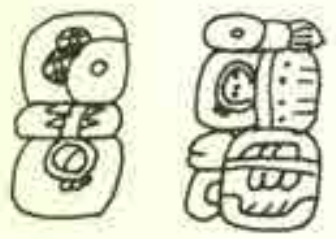

d. $(3,010)$

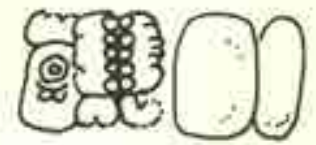

e.
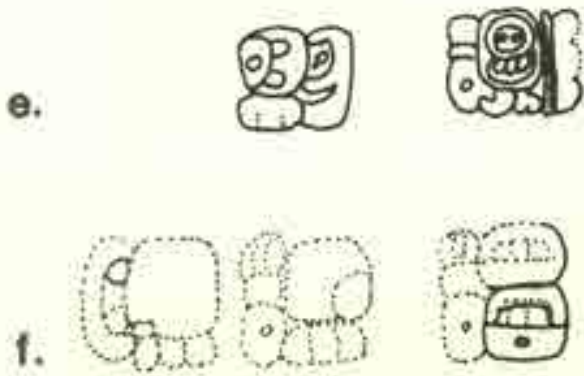

Figure 6. 